Osmaniye Korkut Ata University
Volume 4, Issue 1, 8-16, 2021
OSMANIYE

\title{
Passion Fruit Marmalade Recipe with and without Seeds in Colombia, South America
}

\author{
Muhammad Farhan IQBAL ${ }^{1}$, Muhammad FARHAB ${ }^{2 *}$, Umar FAROOQ ${ }^{3}$, Ayesha QADRY $^{4}$ \\ ${ }^{1}$ University of Kassel and Hochschule Fulda, Faculty of Organic Agricultural Sciences and Öcotrophologie, International Food Business and \\ Consumer Studies, Germany \\ ${ }^{2}$ Department of Pathology, Faculty of Veterinary Science, University of Agriculture Faisalabad, Pakistan \\ ${ }^{3}$ Key Reference Laboratory of Animal Breeding and Genetics, Huazhong Agricultural University, Wuhan, China. \\ ${ }^{4}$ Veterinary Research Institute, Lahore, Punjab, Pakistan \\ ${ }^{1}$ https://orcid.org/0000-0002-4360-6796 \\ ${ }^{2}$ https://www.orcid.org/0000-0003-2519-6268 \\ ${ }^{3}$ https://orcid.org/0000-0002-5394-4270 \\ ${ }^{4}$ https://orcid.org/0000-0003-4229-7706 \\ *Corresponding author: farhab.dvm@gmail.com
}

\section{Research Article}

\section{Article History:}

Received: 1 September 2020

Accept: 25 October 2020

Published online: 2 March 2021

\section{Keywords:}

Passion fruit

Marmalade

Value addition

Colombia

Food business

\begin{abstract}
Colombia is the third largest passion fruit producer of the world after Brazil and Ecuador. The aim of this study was to make noval value added products for passion fruit business owned by small and medium sized farms in Colombia, by developing a product that is easy to produce by farmers. The raw Passion fruits were used as efficient as possible to reduce waste. Two formulas are presented in this study, Formula A with fruit juice only and Formula B with fruit pulp (juice and seeds). Formula A lowered the efficiency of food utilization then Formula B as seeds were wasted in this procedure but it has more consumer acceptance. Both formulas use the rind of passion fruit as gelling material, since no pectin was added. Product was packed in glass jars. This high-quality product, could lead to having a temporary and later on a permanent competitive advantage.
\end{abstract}

\section{Kolombiya ile Güney Amerika'daki Çekirdekli ve Çekirdeksiz Marmelat Tarifi}

\section{Araştırma Makalesi}

Makale Tarihçesi:

Geliş tarihi: 1 Eylül 2020

Kabul tarihi: 25 Ekim 2020

Online Yayınlanma: 2 Mart 2021

\section{Anahtar Kelimeler:}

Çarkıfelek meyvesi

Marmelat

Katma değer

Kolombiya

Gıda işi

\begin{abstract}
ÖZET
Kolombiya, Brezilya ve Ekvador'dan sonra dünyanın en büyük üçüncü çarkıfelek meyvesi üreticisidir. Bu çalışmanın amacı, çiftçiler tarafından üretilmesi kolay bir ürün geliştirerek Kolombiya'daki küçük ve orta ölçekli çiftliklerin sahip olduğu çarkıfelek meyvesi işletmeleri için özgün katma değerli ürünler üretmektir. Olgunlaşmamış çarkıfelek meyveleri, israfı azaltmak için olabildiğince verimli kullanıldı. Bu çalışmada iki formül sunulmuştur, sadece meyve sulu Formül A ve meyve özlü Formül B'dir (meyve suyu ve tohumlar). Formül A, gıda kullanımının verimini düşürdü, daha sonra bu prosedürde tohumlar israf edildiğinden Formül B'yi düşürdü, ancak daha fazla tüketici kabulüne sahiptir. Pektin eklenmediği için her iki formül de çarkıfelek meyvesinin kabuğunu jelleştirici malzeme olarak kullanmaktadır. Ürün cam kavanozlarda paketlenmiştir. Bu yüksek kaliteli ürün, geçici ve daha sonra kalıcı bir rekabet avantajı sağlayabilir.
\end{abstract}

To Cite: Iqbal MF., Farhab M., Farooq U., Qadry A. Passion Fruit Marmalade Recipe with and without Seeds in Colombia, South America. Osmaniye Korkut Ata Üniversitesi Fen Bilimleri Enstitüsü Dergisi 2021; 4(1): 8-16.

\section{Introduction}

Colombia is the third largest passion fruit producer of the world after Brazil and Ecuador [1]. The Codex Alimentarius standard [2] 296, the Colombian organism in charge of developing food standards (ICONTEC) [3] with their standard 285 and the German standard (KonfV) [4] written by the Ministry of Justice, defines the jam as: "the product brought to a suitable consistency, made from the whole fruit, pieces of fruit, the un- 
concentrated and/or concentrated fruit pulp or fruit puree of one or more kinds of fruit, which is mixed with foodstuffs with sweetening properties as defined in Section 2,2, with or without the addition of water. It is formulated by theconcentration of a fruit juice, mixed with a sweetener and water. However, the addition of water could be omitted. Jams can be kept at room temperature before opening because of their high content of sugar. The standards express that these products must have a minimum of $55 \%$ of sugar when comparing to its total weight [2-4]. In this project, the production of jam is proposed as a way for farmers to gain more economical resources.

In concrete, to connect this project to reality and after an online research, an existing project in Colombia was found. This project was located at the eastern part of Colombia, the Cauca Valley and to be more specific, at the municipality of Buga. This alliance was formed with the support of several organizations, mainly by "AGROSASA" which stands for: "Asociación Agropecuaria Sandrana y Samaria" (Agricultural Association Sandrana and Samaria), which by the year 2007 has 40 beneficiaries.

The target consumers of local producers are the local markets of the same state or the states that are adhacent to them [5] by the change from being just "producers" to "processers" and get involved in marketing activities for their own products. The "local" know-how would make it easier for them to deal with regional markets and in the end, international markets [5].

The aim was to develop possible solutions to increase the added value for passion fruit produced by small and medium sized farms in Colombia, by developing a product that is easy to produce by farmers. The specific objectives were: Increasing farmers' profit by processing the fruits, motivating farmers to process the fruits, promoting awareness regarding the nutrutive values of passion fruit.

\section{Materials and Methods}

\section{Raw Material Description}

The fruits were used as efficient as possible to minimize the waste. Therefore, raw passion fruits were used completely. Two formulas are presented below, Formula A with fruit juice only and Formula B with fruit pulp (juice and seeds).
Both formulas use the rind of passion fruit as gelling material, since no pectin was added.

The type of sugar that was used in this project was sucrose [2-4]. A balanced diet should contain 55$60 \%$ of carbohydrates and from $10-20 \%$ should come from disaccharides such as sugar [6]. Sugar lowers the water activity of a food product. The amount of sugar added has to be proportional to prevent spoiling and gel formation [7].

Pectin is a polymeric carbohydrate of high molecular weight and is found in all plants. Typical conditions for jam making are: $\mathrm{pH}$ of 2,83,4 [8]. Generally, pectin is added in jam making process. Fortunately, passion fruit contains natural pectin in its white part of the skin (rind), so there was no need to add artificial pectin [7].

\section{Strategy and Product Definition}

The product that was developed was a jam without additives nor preservatives that can be consumed by anyone from young children to seniors. The jam will be sold in glass jars (previously sterilized and sealed) that can contain 250 grams.

\section{Formulations and Methods}

We presented two formulas. One formula was done at the Universidad San Francisco de Quito (Quito, Ecuador) during a Fruits and Vegetables Processing Lab in 2007. Passion fruit used was the same that was found at Colombia (yellow). The second formula was tested in an experimental kitchen at the University of Applied Sciences in Fulda, Germany. The fruits used for that purpose were the ones available in the German market i.e. purple.

\section{Formula A}

Adapted from Carvajal's method [9], the ingredients used to make jam are passion fruits, sugar [2-4], water and pectin. Pectin was used to get standardized quality, but here pectin was not used because the rind contains a significant amount of pectin. The first process was the pulp separation. Fruits are processed and the results are juice (Js) and waste (W). Juice was then processed to be a jam with adding sugar (S) [2-4] and wet rind $(\mathrm{Wr})$ and the result was jam. Hence, based on the total input is equal to the output, an equation was generated as:

$\mathrm{F}+\mathrm{S}+\mathrm{Wr}=\mathrm{J}+\mathrm{W}$ 


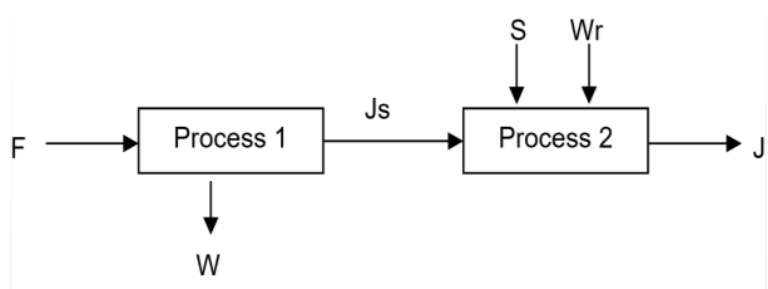

Figure 1. Jam process flow

With this formula, a calculation was generated to produce $1000 \mathrm{~kg}$ jam with $65^{\circ}$ Brix and $20 \%$ fruit content based on Colombian minimal requirement [3]. For this report, calculations are based on the purple passion fruit specification, that is sold in Germany with $16,5^{\circ}$ Brix. The yield for juice was not calculated due to the limited raw material. Generally, passion fruit has $28,13 \%$ of juice [10].

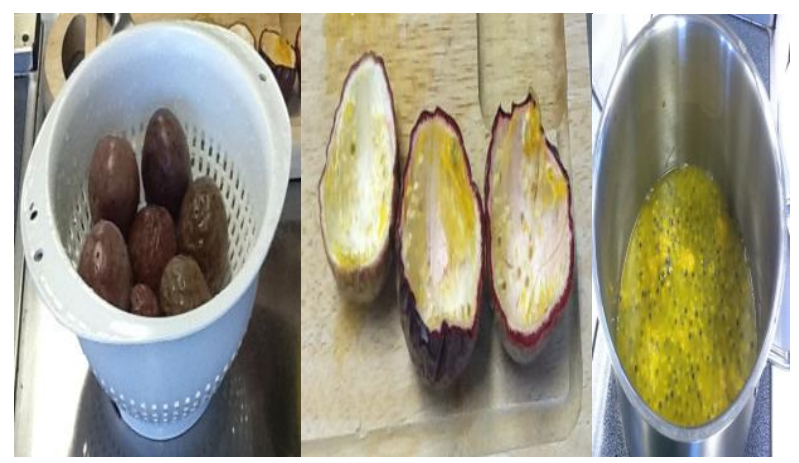

Figure 2. Passion fruits jam making process

To produce 1 ton of jam, $710 \mathrm{~kg}$ of passion fruit was needed to result $200 \mathrm{~kg}$ juice and $180 \mathrm{~kg}$ wet rind and $620 \mathrm{~kg}$ sugar. Water was not directly calculated since it was used to boil the skin.

\section{Formula B}

Formula B was developed by combining several methods from Ali [7], Shahane [11] and Carvajal [9]. Formulation for the passion fruit jam was passion fruit pulp (juice and seeds) (29\%), passion fruit rind after boiled (21\%) and sugar (50\%) [24]. All percentages were by weight. Water was not added directly, but it was used to soften the rind. In the following paragraphs, a complete description of the trial is presented.

- First of all, the fruits were weighted by using a table balance. Then, 386,73 grams fruits were placed into a stainless steel cleaning tank and washed using clean water.

- Fruits were then divided in halves and pulp was removed (Figure 2). Then, $\mathrm{pH}$ was checked using $\mathrm{pH}$ meter. The pulp's $\mathrm{pH}$ was 3,47 . So, there was no need to adjust the $\mathrm{pH}$ to
$2,8-3,5$. If it was necessary, lemon juice or sodium bicarbonate would be added. This pulp and seeds weight 221,65 gram would make up $29 \%$ of the total ingredients.

The entire pulp was used to make use the fruit as optimal as possible. For the trial, seeds were not removed and resulted into an acceptable product. However, this step can be modified according to consumer's acceptance.

- Then, the shells were placed into a pot and boiled in water for 30 minutes or until the rind was soft and translucent. The shells were removed from the water and the rind was scooped out from the outer skin, as can be seen in Figure 3. It was then blended until became a smooth puree using food processor. This made up $21 \%$ of the total ingredients (160,50 gram).

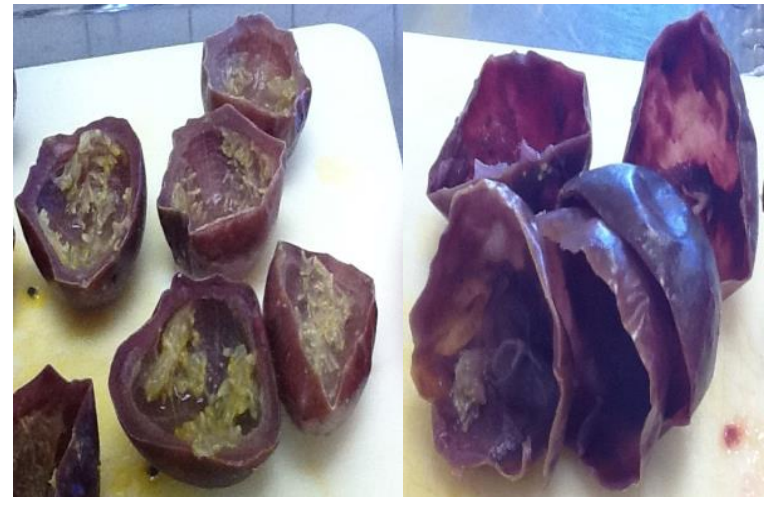

Figure 3. Passion fruit's shells

Regarding to pectin content, it can be said that passion fruit has a considerable amount of it. It was ideal to use fruits that partially ripped so the starch was not converted into sugar yet. Moreover, its acidity was also beneficial for the gelling process [9].

- The pulp, rind puree, and sugar (part 1) (191,08 grams, 25\% of ingredients) were combined together and boiled for 10 minutes. Sugar (part 2) (191,08 gram 25\% of ingredients) was then added and boiled until set [2-4]. It was necessary to stir slowly to prevent the jam from burning in the bottom. The final Total Soluble Solids (TSS) content of a jam should be $65-68 \%$. If the final TSS of jam was lower than $65-68 \%$ the shelf life will be reduced. The jam will have a runny consistency and bacteria and moulds will be able to grow in the product [7].

- In the beginning, the Brix was $16,5^{\circ} \mathrm{C}$, while at the end, it was $70,4^{\circ} \mathrm{C}$. This difference 
occurs because sugar was added and this increased the TSS. Sugar was added in two parts, half at the beginning and half at the concentration stage to speed up the evaporation stage.

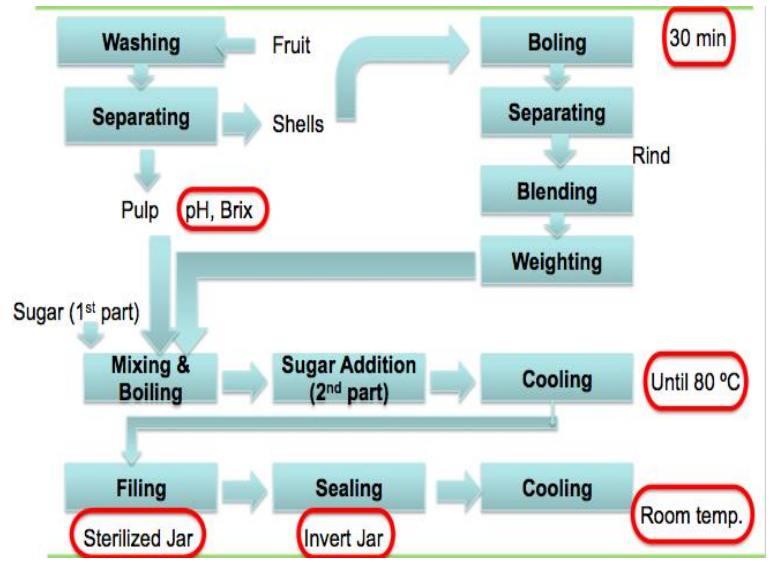

Figure 4. Workflow for processing of marmalade of passion fruit

This helps to avoid the pectin precipitation [9]. Water content was reduced to concentrate the fruit by boiling the mixture as fast as possible. At the same time since the amount of sugar was high, temperature was not exceeded above $160^{\circ} \mathrm{C}$ or caramelisation might occur. The total weight of the jam obtained was 695,04 grams. This number was less than the total of raw material weight. This happened due to water evaporation and some jam that was left sticking on the pot.

- Glass jars and lids were washed and boiled in water for 10 minutes to sterilise them. They were removed using tweezers and drained

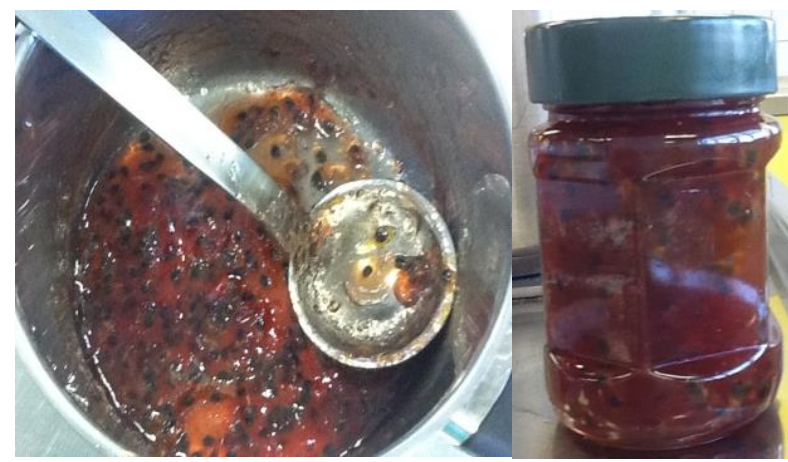

upside down. Jam was then poured into jars, leaving $0,5-1 \mathrm{~cm}$ head space. The head space

Figure 5. Passion fruit jam

is the distance between the product and the lid [13]. Then, the lids were opened and closed instantly to let the steam out and to avoid the presence of condensed water inside the jar at around $85^{\circ} \mathrm{C}$ to avoid steam formation [14]. If there was water, moulds could grow inside the product as the sugar concentration at the surface of the jam is diluted. around $85{ }^{\circ} \mathrm{C}$ to avoid steam formation [14].

- The last step was cooling. The jars were not moved while cooling to avoid gel formation. The gel starts to form as the temperature of the jam decreases (about $55^{\circ} \mathrm{C}$ ) and continues until it was cold [7]. The jar were placed on a table and cooled at room temperature for 12 to 24 hours. The seals were checked 12-24 hours after sealing for leaks and broken seals by pressing-down the lid (Figure 6). If the jars were correctly sealed, the lids will be sucked down tight. In contrast, if sealing was performed incorrectly, it will flex and make a popping sound on each tip [13].

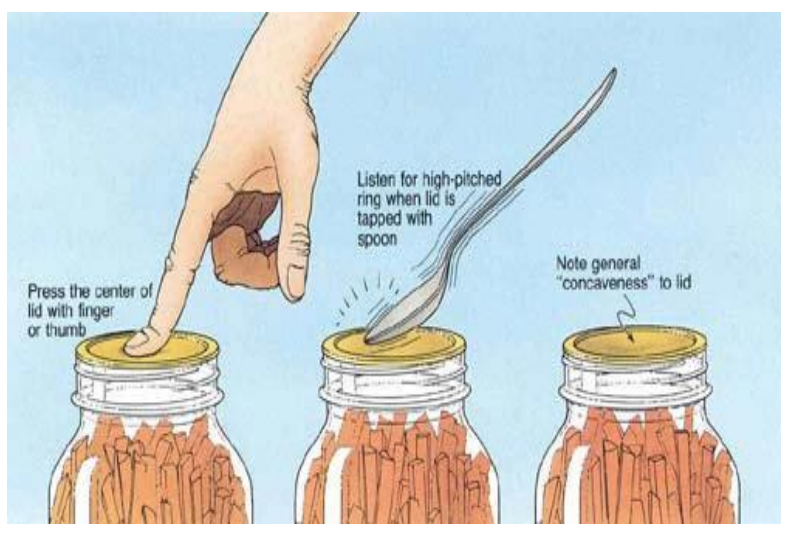

Figure 6. Checking seals Source: Benivia [15]

Based on the CODEX standard for jam (Codex Stan 296-2009), the quantity of passion fruit ingredients used as a percentage of the finished product shall not be less than $8 \%$ in general. For this trial, the product has $54,98 \%$ of fruit ingredients (pulp, seeds, rind).

This product fulfils the general requirement, which was "the end product shall be of an appropriate gelled consistency, having normal colour and appropriate flavour of the fruit ingredient used in the preparation of the mixture. It shall be free from defective materials normally associated with fruits. Jelly and extra jelly shall be reasonably clear or transparent" [2]. Requirements for food additives for acid, antifoaming, colours, preservatives and flavourings are not applied, since this product was naturally produced.

The calculations for this report are based on the production of 1 Ton of jam. This volume was chosen because it is commonly the minimumally managed by processing companies. Using the traditional method of balancing raw materials, all 
the calculations were done. To produce $1000 \mathrm{~kg}$ jam using Formula B, $500 \mathrm{~kg}$ passion fruit is needed to make $290 \mathrm{~kg}$ pulp and $210 \mathrm{~kg}$ wet rind and $500 \mathrm{~kg}$ sugar. The summary of the ingredients and quantity needed to produce $1000 \mathrm{~kg}$ using Formula A and B can be seen in Table 1 .

Table 1. Ingredients and quantities for formula $A$ and B

\begin{tabular}{lll}
\hline \multirow{2}{*}{ Ingredients } & \multicolumn{2}{c}{ Quantity (kg) } \\
\cline { 2 - 3 } & Formula A & Formula B \\
\hline Pulp & - & 290 \\
Juice & 200 & - \\
Sugar & 620 & 500 \\
Wet rind & 180 & 210 \\
\hline
\end{tabular}

\section{Machinery and Equipment}

The machinery and general equipment needed for producing marmalade were from COMEK ${ }^{\mathrm{TM}}$ [16] and is presented in Table 2. All of them are made of stainless steel because it does not react with the acidity of the fruit. If there is no stainless steel equipment available, the condition of equipment should be free of rust [7].

Table 2. Machines and equipment needed for the production of passion fruit jam

\begin{tabular}{cc}
\multicolumn{2}{c}{ production of passion fruit jam } \\
\hline Machines & Equipment \\
Balance & Tank for Manual Packaging \\
Kettle & Thermometer \\
Pulp Remover & pH Meter \\
\hline
\end{tabular}

\section{Market's Characteristics}

Market size is affected by a number of variables. In production, it is essential to know these variables, as they decide the survival in the market. First, it is necessary to know how many companies that produce the same product are existing in market and how much the turnover is? Then observe price, quality and market shares of competitors. Second important variable is to identify potential consumer, the area which influences them need to be determined as supermarket, food distributor, food stores, vegetarian shops, restaurants, hotels and businesses. With the help of these variables market size can be determined [17].

Table 3. Percentage of sales according to place

\begin{tabular}{ll}
\hline Place & Percentage sale \\
\hline Convenience stores & $32 \%$ \\
Specialty shops & $22 \%$ \\
Restaurants & $15 \%$ \\
Individuals & $11 \%$ \\
Supermarkets & $10 \%$ \\
\hline
\end{tabular}

\begin{tabular}{ll}
\hline Hypermarkets & $5 \%$ \\
Business & $5 \%$ \\
\hline
\end{tabular}

Source: Alcaldia de Medellin [17]

\section{Potential Clients}

Target market of the product should be decided in order to market the product at the place where the consumers usually purchase it. Table 3 shows the place where jams are purchased in the area of Medellin, which will be the target market later once the regional market was established [17].

On Table 3, convenience stores and speciality stores have the highest percentage of sales due to the amount of stores and they are found everywhere. According to geographical location, percentage of sales can be seen on Table 4 .

Table 4. Percentage of sales according to geographical area

\begin{tabular}{cc}
\hline Geographical scope & Percentage sales \\
Metropolitan area & $52 \%$ \\
Regional & $24 \%$ \\
Communal & $15 \%$ \\
Neighborhood & $6 \%$ \\
National & $3 \%$ \\
\hline Source: Alcaldia de Medellin [17]
\end{tabular}

Table 4 shows that more than half of sales are made in the metropolitan area. So once the market in the metropolitan area is established, it is easier to penetrate the rest of the country. Still it is necessary to adapt to the conditions of the market and then adjusting the strategies and sales promotion [17].

\section{Potential Competitors}

Potential competitors always affect the entry or exit into a new market. If the barrier on entry is low, then there will be many companies willing to enter the market. If there is large number of businesses are already there, then barriers on exit is high a strong competition exists [17].

The potential competitors are all companies that are already in the Colombian market, selling other jam flavours. They all sell at the major Colombian supermarkets such as Exito and Colsubsidio. After a colleague's visit to these supermarkets in the city of Bogotá, some of the brands that they sell were observed. In Colombia, only one company offers passion fruit jam, which is positive for the product. Generally, they produce jams from commonly known fruits such as: strawberry, blackberry or peach. From these companies, only one is not Colombian, which is "Smuckers", and 
is imported from the United States. The difference in price from the Exito ${ }^{\mathrm{TM}}$ and the others is due to its clear low cost strategy because it is a supermarket's brand. Nowadays supermarkets like to hire companies for producing products with their name and they sell them at low prices. Another remark is that the differences in prices are relatively large and even if the amount sold per jar is the same. Probably this is due to the fact that the investigation was done in two common supermarkets and the way of calculating the final price is different.

\section{Results and Discussion}

\section{SWOT Analysis}

Five years from now, the jam produced by the members of the cooperative will be one of the market leaders of the exotic fruit jams in Colombia. Therefore, SWOT analysis was conducted to construct a strategic planning to reach the target. SWOT stands from Strength, Weakness, Opportunities and Threats. Strength and weakness are analysed internally to optimally use the opportunities and overcome threats.

\section{Strategies:}

S-O: With secured resources and natural product fulfilling the need of passion fruit jam in Colombia.

Having "secured resources" means that the main raw material, meaning passion fruit, is obtained from the existing plantation owned by the cooperative's members (backward vertical integration). This is really positive because the problems that normally exist with suppliers do not occur and the price is relatively stable. Moreover, the employees, by being members of the cooperative have an extra motivation. This cause they do not only earn their salaries but some of the profits. Having motivated employees is crucial for having a good work translated into a high quality product. In what has to do with the jam itself, the fact that it was natural (no pectin nor additives added) was a strength of this product and was it was noval from the products that were already in the market and the usable parts of the fruit are used completely. All of these strengths are combined with the opportunities in an already existing market for jams and marmalades and a promising one for passion fruit jam. Furthermore, the cooperative was already established, which makes it easier to launch the project.
W-O: By getting people to invest in this project from an existing cooperative, the internal problems can be minimized and more technical assistance will be received.

The main weakness that this project has was the lack of resources (money) for starting the business. Therefore, the right strategy was to get people to invest on it. When having the economical issue solved, technical assistance could be hired, not only for improving the production process itself but for helping to have a high quality passion fruit too. The last one was to do with the possible affectations to the core activity (planting the fruit), when having the pressure from processing it. Moreover, with this strategy, the weakness of internal problems were also solved. This was because there were no confrontations related to who invested more or less amount of money. This strategy is aided by the opportunity that exists because the cooperative was already working. Investors are usually more interested if there is something that is a current reality. By implementing this strategy, all of the other opportunities were utilized since the production for the Colombian market is assured.

S-T: By having an innovative product and controlled supply of raw material, consumption of passion fruit jam will be promoted.

This strategy was based on the advantage of having a natural product in a country in which its flavour was not common, but there was a consumption of other jams. It helps to reduce the threat of other jam's producers cause as mentioned, it differentiates from the others (flavour and $100 \%$ natural). Moreover, the strength of having an assured supplying of raw material makes it an important advantage over other competitors, which have to struggle with usual market problems.

W-T: By having a controlled process from "farm to finished product" and a differentiated idea threats from the competitors and environmental effects will be reduced.

Basically, having a controlled process by external people could reduce the weakness of not knowing how to process the fruit and the threat of environmental effects. With "external people" it is meant someone who is a professional in the field. On the other hand, the part of the strategy that mentions having a differentiated idea, helps to reduce the threat of companies that produce jams 
with commonly found flavours e.g. strawberry or blackberry.

All the things mentioned above lead to a strategy. According to Porter [22], there are three strategies that can be applied on business: cost advantage, differentiation advantage and market segmentation. In cost leadership, the company wins because of their low cost. They can sell products cheaper as compared with competitive products. They have this advantage because they reached purchasing power of the customers more easily. The more quantity produced, the less costly the process is, upto some point. This is due to low operating cost. Differentiation strategy is typically picked when the market is competitive or saturated. Product is differentiated from others to serve the specific needs of customers. This character is unique and difficult to be copied. Usually when the product is the same as others, image differentiation is applied. In segmentation strategy, the product serves distinct groups with special needs.

In this case, this jam producer was still unable to reach it. Since it was a new established company, it needs to gain more experience to optimize the process. The last point here is to get raw material in low price, which is feasible, since the cooperative gets the raw material directly from the farmers. In general, it is unlikely to apply cost leadership in this new established company. It is also not suitable to apply segmentation strategy, since this product is meant to be consumed by wide range of age and social class. Therefore, here differentiation strategy is applied. This jam is different from other jam in the market because it has new flavor with only natural ingredients that has good health benefits and produced regionally with no child labour.

\section{Demand}

According to some studies made by an important Colombian company in charge of analyzing markets called "Raddar" [23] Consumer Knowledge Group, nowadays, Colombians give most of their salaries for buying food. This is important for the appearance of projects such as the one presented in this report, because people have food as a priority.

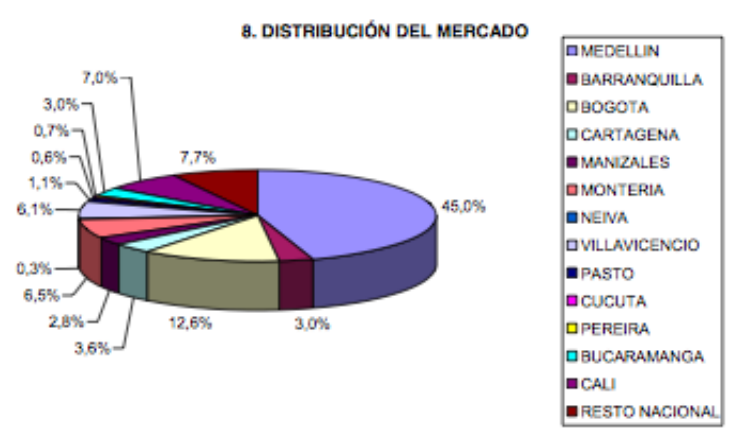

Figure 7. Marmalade market distributions according to social classes. Source: Raddar [23]

\section{Market Size}

The marketing research company presented the following graph (Figure 7) when analysing sales according to the social class. It is shown that people from the middle class are the ones who buy the most amount of marmalade with a $79 \%$, followed by the lower class with only $11 \%$ and finally the high class with slightly less, $10 \%$. This information shows that marmalade is probably not affordable for people in the lower class or simply they don't consume it. In what has to do with people from the high class, it can be deduced that even though they can afford it, they do not buy it because they choose other products instead. It is from common knowledge that people with more economic power and education can afford different types of foods even imported ones such as the American Peanut Butter or Maple Syrup. When looking at this tendency, marketing efforts for the passion fruit marmalade should be directed to people from the middle class.

\section{Demand Projection}

In the future, the product will be also commercially throughout the Colombia. Therefore, it was important to know the cities where there was the highest consumption of marmalade. From Raddar's study [23] (Figure 8), it can be concluded that Medellín, one of the biggest cities in Colombia consumes the most amount of marmalade with $45 \%$. In second place, the capital Bogota with $12,6 \%$ and in the third the cities that are not mentioned in the list with $7,7 \%$. Efforts should be made to introduce the marmalade in cities such as Medellín and Bogotá due to their importance in the market distribution. However, to being able to fulfil their demands, the company has to be big enough because they are cities with millions of inhabitants. 


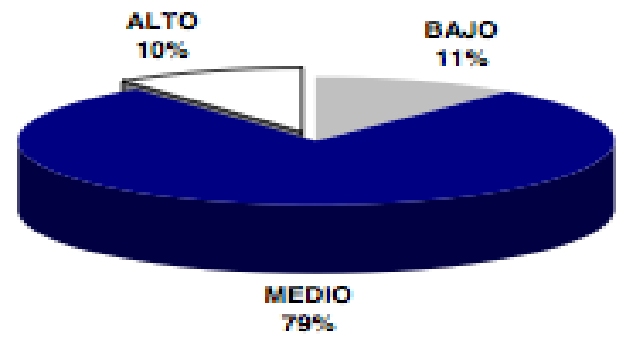

BAJO $=$ MEDIO DALTO

Figure 8. Marmalade market distributions according to cities. Source: Raddar [23]

\section{Conclusion}

Raw Passion Fruits are processed to give more value to the product and at the same time, increase the farmer's profit from the cooperative AROGASA. The easiest product that they could produce from the fruit is jam, which was chosen for this project. There were two formulations presented in this report. One of them is using the seeds of passion fruits (since they are edible), but many people do not like them on their jams. That is why another formula was presented where they are separated and discarded. However, this lowers the efficiency.

After analysing a previous experience from one of the group members, it can be concluded that international markets can be covered once the business established and it will run well at a regional level. It can also be exported provided that there will be the sufficinet supply of the raw materials. This project was a start for a regional company that after gaining experience in the immediate region could expand to other areas. Therefore, it was designed to have the minimum amount of machines and personal that could be used in this type of process.

In this report, the cost for building facilities, product transportation and storage are not included. If one wants to establish the whole production process from the beginning, these costs should be calculated. Therefore, it could be stated that the calculations included in the report are only made to get the rough idea of what this type of business implies and the potential benefits. Moreover, when obtaining real and reliable data from marketing research studies, analyses such as the breakeven point should be made. Deeper research and experiments in the field are recommended.
It can also be stated that the product has potential due to the popularity that jam has in the Colombian market. Strategies such as getting initial financial aid, a strong internal organization, and last but not least, a high-quality product, could lead to having a temporary competitive advantage. Later on, if the success is maintained, a permanent competitive advantage could be obtained.

\section{Statement of Conflict of Interest}

Authors have declared no conflict of interest.

\section{Author's Contributions}

The contribution of the authors is equal.

\section{References}

[1] Corporación Colombia Internacional. Inteligencia de Mercados Perfil de Producto: Maracuyá. 19. 2011. Available online: http://www.cci.org.co/cci/cci_x/Sim/Perfil\%20de $\% 20$ Productos/perfil\%20producto\%2019\%20final .pdf (accessed on 5 May 2011).

[2] Codex Alimentarius. CODEX standard for jams, jellies and marmalades 2009; codex stan 296.

[3] ICONTEC. Norma Técnica Colombiana, NTC 287- Frutas Procesadas. Mermeladas y Jaleas de Frutas. Bogotá, Colombia: Instituto Colombiano de Normas Técnicas y Certificación (ICONTEC), 2007.

[4] Bundesministerium der Justiz. Verordnung über Konfitüren und einige ähnliche Erzeugnisse 2003; Konfitürenverordnung - KonfV.

[5] Castro LJ. Personal Communication. 2011.

[6] Arthey D., Ashurst PR. Procesado de Frutas. Editorial Acribia, Zaragoza, 1996.

[7] Ali SA. Passion Fruit Jam: Small-Scale Production. Available online: http://practicalaction.org/practicalanswers/product _info.php?products_id=115; 2009 (accessed on 11 April 2011).

[8] Nordic Sugar. The Functional properties of sugar, Available online: http://www.nordicsugar.com/fileadmin/Nordic_Su gar/Brochures_factsheet_policies_news/Downloa d_center/Functional_properties_of_sugar_on_a_te chnical_level/Functional_prop_on_tech_level_uk. pdf 2011; (accessed on 16 November 2011). 
[9] Carvajal F. Manual de Laboratorio de Procesamiento de Frutas-Universidad San Francisco de Quito. Quito, Ecuador 2007, USFQ.

[10] Bates RP., Morris JR., Crandall PG. Principles \& practices of small - and mediumscale fruit juice processing, FAO Agricultural Services Buletin 146. 2001. Available online: ftp://ftp.fao.org/docrep/fao/004/y2515e/Y2515E0 6.pdf (accessed on 9 November 2011).

[11] Shahane J. Passion fruit jam, 2007; Available online:

http://thecookscottage.typepad.com/curry/2007/10/pass ion-fruit-j.html (accessed on 9 November 2011).

[12] Harris L., Suslow T. Principles of home canning. United States Department of Agriculture and Cooperative State Research, Education and Extension Service 2011. Available online: http://ucfoodsafety.ucdavis.edu/files/26457.pdf (accessed on 1 November 2011).

[13] Fellow P. UNIDO Technology manual-small scale-fruit and vegetable processing and products, Vienna, Austria, The United Nations Industrial Development Organization 2004.

[14] Benivia. Available online: http://www.pickyourown.org/canningtips.php 2011; (accessed on 1 November 2011).

[15] Comek. Comek-Equipos Para la Industria Alimentaria 2011. Available online: http://www.comek.com.co/ (accessed on 18 November 2011).

[16] Alcaldia de Medellin. Cultura E- Produccion de Conservas y Mermeladas 2007; Available online:

http://www.culturaemedellin.gov.co/sites/CulturaE/Cul turaE/Guias_empresariales/01_Produccion_conservas_ mermeladas.pdf (accessed on 8 December 2011).

[17] Porter ME. Competitive advantage: creating and sustaining superior performance: with a new introduction. The Free Press 1998; New York.

[18] Raddar Consumer Knowledge Group, Primer Estudio de Marcas y Estrategias en ColombiaNoviembre 2011. Available online: http://www.raddar.net/index.html (accessed on 6 January 2011). 